\title{
Methanobrevibacter millerae sp. nov. and Methanobrevibacter olleyae sp. nov., methanogens from the ovine and bovine rumen that can utilize formate for growth
}

\author{
Suzanne Rea, ${ }^{1}$ John P. Bowman, ${ }^{2}$ Sam Popovski, ${ }^{3}$ Carolyn Pimm ${ }^{4}$ \\ and André-Denis G. Wright ${ }^{5}$
}

Correspondence

Suzanne Rea

Suzy.Rea@csiro.au

\author{
${ }^{1}$ CSIRO Minerals, cnr Brand and Townsing Drives, Bentley, Western Australia 6102, Australia \\ ${ }^{2}$ Australian Food Safety Centre, University of Tasmania, Private Bag 54, Hobart, Tasmania \\ 7001, Australia \\ ${ }^{3}$ CPSU, Level 1, 40 Brisbane Avenue, Barton, Australian Capital Territory 2600, Australia \\ ${ }^{4}$ CSIRO Livestock Industries, Underwood Avenue, Floreat Park, Western Australia 6014, \\ Australia \\ ${ }^{5}$ CSIRO Livestock Industries, 306 Carmody Rd, St Lucia, Queensland 4067, Australia
}

In an attempt to design anti-methanogen vaccines that would decrease methane emissions from ruminants (Wright et al., 2004a), methanogens were enriched and isolated (Kicic, 1995; Munyard, 2000) from ovine and bovine rumen contents. Phylogenetic surveys of ovine rumen contents (Wright et al., 2004b) were also conducted. The studies revealed that the majority of methanogens from the rumen

The GenBank/EMBL/DDBJ accession numbers for the 16S rRNA gene sequences of strains $\mathrm{ZA}-10^{\top}$ and $\mathrm{KM} 1 \mathrm{H} 5-1 \mathrm{P}^{\top}$ are AY196673 and AY615201.

Details of growth parameters and DNA-DNA hybridization and 16S rRNA gene sequence similarity values for strains $\mathrm{ZA}-10^{\top}$ and $\mathrm{M} 1 \mathrm{H} 5-$ $1 \mathrm{P}^{\top}$ in comparison with Methanobrevibacter reference strains are available as supplementary material in IJSEM Online. contents of the Western Australian sheep and cattle studied belonged to the genus Methanobrevibacter. The aim of this research was to determine whether the Western Australian isolates represented novel species of the genus Methanobrevibacter or were members of recognized species.

A polyphasic approach was taken to characterize four strains by using the minimal standards as detailed by Boone \& Whitman (1988). Three strains were isolated from bovine rumen contents (strains AK-87, OCP and ZA- $10^{\mathrm{T}}$ ) and one strain from ovine rumen contents $\left(\mathrm{KM} 1 \mathrm{H} 5-1 \mathrm{P}^{\mathrm{T}}\right)$. The strains were purified by serial dilution on bottle plates with modified BRN medium with $\mathrm{H}_{2} / \mathrm{CO}_{2}(80: 20)$ at $200 \mathrm{kPa}$ (Balch et al., 1979; Miller et al., 1982). For purification of strain OCP, a mixture of four antibiotics was used $\left(\mathrm{ml}^{-1}\right.$ : 
$0.16 \mathrm{mg}$ cephalothin, $0.04 \mathrm{mg}$ clindamycin, $0.10 \mathrm{mg}$ ampicillin and $0.10 \mathrm{mg}$ vancomycin) in $5 \mathrm{ml}$ medium.

All incubations were at $39^{\circ} \mathrm{C}$ on an orbital shaker operating at 160 r.p.m. BRN medium was used for growth experiments, phenotypic tests and the production of cells for DNA extraction. A $2.5 \%$ cysteine sulfide solution was used $\left(0.02 \mathrm{ml}^{-1}\right)$ to reduce the medium just prior to inoculation. Growth was determined by measuring the optical density at $660 \mathrm{~nm}\left(\mathrm{OD}_{660}\right)$ with a Jenway 6300 spectrophotometer. Cultures were maintained by serial transfers in BRN medium every 3-4 weeks using a $10 \%(\mathrm{v} / \mathrm{v})$ inoculum. Long-term preservation followed the protocol of Miller (2001).

For 16S rRNA gene sequencing, DNA was extracted and purified following the methods of Wright et al. (2004b). PCR amplification and sequencing procedures were as detailed by Wright \& Pimm (2003). The phylogenetic software package PHYLIP version 3.62c (Felsenstein, 2004) was used to calculate sequence similarity and evolutionary distances between pairs of nucleotide sequences of 13 methanogen strains by using the Kimura two-parameter correction model (Kimura, 1980). Methanomicrobium mobile $\mathrm{BP}^{\mathrm{T}}$ was used as the outgroup. A distance-matrix tree was then constructed by using the Fitch-Margoliash method with the program FITCH. Bootstrap analysis (Felsenstein, 1985) (1000 replicates) was also performed.

For genotypic characterization of the strains, DNA was extracted and purified from $2-4 \mathrm{~g}$ wet cells by using a modified procedure of that of Marmur \& Doty (1962). These modifications included incubation of cells overnight at $45^{\circ} \mathrm{C}$ in proteinase $\mathrm{K}$ and at least $3 \mathrm{~h}$ incubation in $20 \%$ SDS at room temperature, followed by mechanical disruption (4200 r.p.m. for $20 \mathrm{~s}$ repeated three times) on a mini bead-beater. The quality of DNA was checked by measuring the $A_{260} / A_{280}$ ratio on a Varian Cary $1 \mathrm{E}$ spectrophotometer. The DNA G $+\mathrm{C}$ content was determined from thermal denaturation profiles (Sly et al., 1986).

DNA reassociation was analysed between strains that showed $\geqslant 97 \% 16 \mathrm{~S}$ rRNA gene sequence similarity, between strains ZA- $10^{\mathrm{T}}$ and KM1H5- $1 \mathrm{P}^{\mathrm{T}}$ and their closest recognized relatives. The method of Bowman et al. (1998) was followed using Methanobrevibacter ruminantium $\mathrm{M1}^{\mathrm{T}}$ as the reference strain. All samples were tested for control values, e.g. Methanobrevibacter ruminantium $\mathrm{M}^{\mathrm{T}}$ versus Methanobrevibacter ruminantium $\mathrm{Ml}^{\mathrm{T}}$ (hybridization value $=100 \%$ ) and mixed with other strains (hybridization value $<100 \%$ ) to determine the degree of DNA-DNA reassociation between strains. Hybridization values of $<25 \%$ were not statistically significant as they were within values consistent with random hybridization. Hybridization was performed in $2 \times$ SSC at an optimal renaturation temperature of $73^{\circ} \mathrm{C}$ (Huß et al., 1983).

Cell walls were extracted from strains KM1H5-1P ${ }^{\mathrm{T}}$, AK-87 and $\mathrm{ZA}-10^{\mathrm{T}}$ and reference strains Methanobrevibacter arboriphilus $\mathrm{DH}-1^{\mathrm{T}}$, Methanobrevibacter ruminantium $\mathrm{M}^{\mathrm{T}}$ and Methanobrevibacter smithii $\mathrm{PS}^{\mathrm{T}}$, by using the method of Konig (1995). Protein concentrations of the cell walls and intracellular fractions were determined by using the Bio-Rad protein assay. The carbohydrate concentration of the cell walls was determined by using the Pierce glycoprotein carbohydrate estimation kit.

Phenotypic characterization of the strains included substrate utilization with an emphasis on optimizing growth on formate plus $\mathrm{CO}_{2} / \mathrm{N}_{2}(20: 80)$, nutritional requirements, growth in bile salts and sodium chloride and the temperature and $\mathrm{pH}$ range for growth. Cell morphology, size, motility and Gram reaction (Gerhardt et al., 1994) were determined by using a Leitz Aristoplan microscope with phase-contrast optics.

All strains were tested in duplicate for their ability to utilize $100 \mathrm{mM}$ sodium formate, $50 \mathrm{mM}$ sodium acetate, $50 \mathrm{mM}$ methanol, $50 \mathrm{mM}$ ethanol, $50 \mathrm{mM}$ 2-propanol, $50 \mathrm{mM} 2$ butanol, $50 \mathrm{mM}$ methylamine and $50 \mathrm{mM}$ trimethylamine as growth substrates in the presence of $\mathrm{CO}_{2} / \mathrm{N}_{2}(20: 80)$. To optimize the growth of two strains on formate plus $\mathrm{CO}_{2}$, growth rates and yields on $\mathrm{H}_{2} / \mathrm{CO}_{2}(80: 20)$ as compared with formate plus $\mathrm{CO}_{2}$ were determined. Strains $\mathrm{ZA}-10^{\mathrm{T}}$, $\mathrm{KM} 1 \mathrm{H} 5-1 \mathrm{P}^{\mathrm{T}}$ and two reference strains (Methanobrevibacter ruminantium $\mathrm{M}^{\mathrm{T}}$ and Methanobrevibacter smithii $\mathrm{PS}^{\mathrm{T}}$ ) were grown in $\mathrm{BRN}$ medium in triplicate cultures with either $\mathrm{H}_{2} / \mathrm{CO}_{2}(80: 20)$ pressurized to $200 \mathrm{kPa}$ or sodium formate plus $\mathrm{CO}_{2} / \mathrm{N}_{2}(20: 80)$ pressurized to $100 \mathrm{kPa}$. The concentration of sodium formate in the medium was increased in $70 \mathrm{mM}$ increments from 150 to $440 \mathrm{mM}$ to determine the optimum formate concentration for growth. Sodium tungstate $(0.0016 \mathrm{mM})$ was also added to the trace minerals in formate-grown cultures. Gas production, $\mathrm{pH}$ and substrate consumption were measured. Doubling times and specific growth rates of exponentially growing cultures were determined from $\mathrm{OD}_{660}$ measurements over time by using the method of Prescott et al. (1999).

Gas pressures in the culture tubes were measured with a pressure transducer and the composition of the headspace in culture tubes was determined by injecting a gas sample into a Shimadzu 8A gas chromatograph, equipped with a thermal conductivity detector and data acquisition plotting and analysis software (DAPA chromatography software; Curtin University, Perth, Australia). The column used was $80 / 100$ Carbosieve stainless steel $\left[15^{\prime} \times 1 / 16^{\prime \prime}\right.$ (outside diameter) $(4.57 \mathrm{~m} \times 1.6 \mathrm{~mm})$; Supelco]. Operating conditions for the gas chromatograph were as follows: argon carrier gas, column head pressure, $400 \mathrm{kPa}$; column temperature, $190^{\circ} \mathrm{C}$; injector and detector temperature, $250^{\circ} \mathrm{C}$; and injection volume, $1.0 \mathrm{ml}$ with a Velco valve injecting loop.

Formate concentrations were analysed via HPLC by using a Waters system equipped with two Aminex HPX-87H organic acid columns $(300 \times 7.8 \mathrm{~mm})$ connected in series, with a microguard column and a column heater. Formic acid was eluted by using a mobile phase of $0.2 \%$ phosphoric 


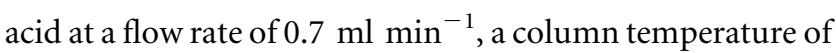
$65^{\circ} \mathrm{C}$ and UV detection at $210 \mathrm{~nm}$.

Nutritional supplements to determine the minimum requirements for growth were tested in the basal salts of BRN medium. Growth was confirmed after a third transfer culture had reached an $\mathrm{OD}_{660} \geqslant 0.13$ in which a control tube containing inoculum but without substrate was used to 'zero' the spectrophotometer. The final concentrations of nutrients tested were $25 \mathrm{mM}$ acetate, $0.04 \mathrm{mg}$ yeast extract $\mathrm{ml}^{-1}$ and $0.04 \mathrm{mg}$ trypticase peptone $\mathrm{ml}^{-1}$. A requirement for $0.01 \mathrm{mg} 2$-mercaptoethanesulfonic acid (co-enzyme $\mathrm{M}$ ) $\mathrm{ml}^{-1}$ and $0.02 \mathrm{ml}$ of a fatty acids solution $\mathrm{ml}^{-1}$ was also tested. The fatty acids solution contained valeric, isovaleric, 2-methylbutyric and isobutyric acid at $2.5 \%(\mathrm{v} / \mathrm{v})$ each.

Cells from exponentially growing cultures were used to test for susceptibility to lysis by using $10 \%$ SDS and for bile sensitivity by using $2 \%$ bovine bile (ox gall powder) and $0.1 \%$ sodium deoxycholate. These were added prior to autoclaving the BRN medium as adding them after autoclaving caused precipitation. Growth was considered to be positive if transfer cultures reached an $\mathrm{OD}_{660} \geqslant 0.13$. Growth in $\mathrm{NaCl}$ was tested at final $\mathrm{NaCl}$ concentrations of $0.1-0.5 \mathrm{M}$ in $0.05 \mathrm{M}$ increments.

Range and optimum temperature for growth were determined for strains KM1H5-1 $\mathrm{P}^{\mathrm{T}}$, OCP, AK-87 and ZA- $10^{\mathrm{T}}$ and for reference strains Methanobrevibacter smithii $\mathrm{PS}^{\mathrm{T}}$, Methanobrevibacter ruminantium $\mathrm{M}^{\mathrm{T}}$ and Methanobrevibacter gottschalkii $\mathrm{HO}^{\mathrm{T}}$ by using a temperature gradient incubator (TGI). The TGI temperature range was $15-45^{\circ} \mathrm{C}$ with $2-3{ }^{\circ} \mathrm{C}$ intervals at 150 r.p.m. The temperature of each of the 48 tube locations was checked by using a temperature logger. Finally, the range and optimum $\mathrm{pH}$ for growth of the strains at $\mathrm{pH} 5-10$ in intervals of $0.5 \mathrm{pH}$ units were determined.

The polyphasic approach taken to characterize the four new strains revealed that they were affiliated to the genus Methanobrevibacter. The DNA G $+\mathrm{C}$ contents were within the range previously given for members of the genus Methanobrevibacter (26-38 mol\%) (Miller, 2001; Miller \& Lin, 2002) (Table 1). Nutritional requirements, growth in bile salts, tolerance of $\mathrm{NaCl}$ and growth temperature range and $\mathrm{pH}$ range for the strains are also detailed in Table 1 . Two of the strains $\left(\mathrm{ZA}-10^{\mathrm{T}}\right.$ and $\left.\mathrm{OCP}\right)$ were able to grow at $\mathrm{pH}$ 5.5. Prior to this study, the only recognized Methanobrevibacter strains reported to be able to grow below neutral $\mathrm{pH}$ were Methanobrevibacter ruminantium $\mathrm{M}^{\mathrm{T}}$ and Methanobrevibacter acididurans $\mathrm{ATM}^{\mathrm{T}}$ (Savant et al., 2002). However, in the present study, it was determined that Methanobrevibacter smithii PS $^{\mathrm{T}}$ and Methanobrevibacter gottschalkii $\mathrm{HO}^{\mathrm{T}}$ were also capable of growth below neutral $\mathrm{pH}$ (Table 1).

The ability of the strains to utilize only $\mathrm{H}_{2} / \mathrm{CO}_{2}(80: 20)$ and in some cases formate plus $\mathrm{CO}_{2}$ as a carbon and energy source is characteristic of the genus Methanobrevibacter. Two of the four strains in this study (ZA$10^{\mathrm{T}}$ and $\mathrm{KM} 1 \mathrm{H} 5-1 \mathrm{P}^{\mathrm{T}}$ ) were able to utilize formate plus $\mathrm{CO}_{2}$. Methanobrevibacter ruminantium $\mathrm{M}^{\mathrm{T}}$ is one of only three

Table 1. Differential characteristics between strains $A K-87, \quad O C P$ and $Z A-10^{\top}$ and $K M 1 H 5-1 P^{\top}$ and other related Methanobrevibacter species

Reference strains: 1, Methanobrevibacter ruminantium $\mathrm{M1}^{\mathrm{T}} ; 2$, Methanobrevibacter gottschalkii $\mathrm{HO}^{\mathrm{T}}$; 3, Methanobrevibacter thaueri $\mathrm{CW}^{\mathrm{T}}$; 4 , Methanobrevibacter smithii PS $^{\mathrm{T}}$. ND, No data available.

\begin{tabular}{|c|c|c|c|c|c|c|c|c|}
\hline Trait & $\mathrm{ZA}-10^{\mathrm{T}}$ & KM1H5-1P ${ }^{T}$ & OCP & AK-87 & 1 & 2 & 3 & 4 \\
\hline Growth on formate & + & + & - & - & + & - & - & + \\
\hline \multicolumn{9}{|l|}{ Nutritional requirements:* } \\
\hline Acetate only & - & + & - & - & - & - & - & - \\
\hline Yeast extract plus trypticase peptone & + & - & + & + & + & + & + & $-\dagger$ \\
\hline Co-enzyme M & - & - & - & + & + & - & - & - \\
\hline Fatty acid solution & - & - & - & + & - & - & - & - \\
\hline Growth with bile salts & - & - & - & - & - & + & - & + \\
\hline Temperature range $\left({ }^{\circ} \mathrm{C}\right)$ & $33-43$ & $28-42$ & $28-42$ & $36-43$ & $33-42$ & $27-41$ & ND & $26-46$ \\
\hline Optimal temperature $\left({ }^{\circ} \mathrm{C}\right)$ & $36-42$ & $36-40$ & $35-39$ & $40-42$ & $35-40$ & $37-41$ & $37 \ddagger$ & $34-46$ \\
\hline $\mathrm{pH}$ range & $5.5-10.0$ & $6.0-10.0$ & $5.5-9.0$ & $6.5-9.0$ & $5.5-7.0$ & $5.0-10.0$ & ND & $5.0-8.5$ \\
\hline pH optimum & $7.0-8.0$ & 7.5 & 7.5 & $7.5-8.5$ & $6.0-7.0$ & $6.5-7.0$ & $7.0 \ddagger$ & $5.5-7.0$ \\
\hline Tolerance of $0.45 \mathrm{M} \mathrm{NaCl}(2.6 \%)$ & + & + & + & - & - & + & - & + \\
\hline Known habitat(s)§ & BRC & ORC & BRC & BRC & BRC & $\mathrm{EF}, \mathrm{PF}$ & $\mathrm{BF}$ & $\mathrm{HF}, \mathrm{S}$ \\
\hline DNA G $+\mathrm{C}$ content $(\mathrm{mol} \%)\left(T_{\mathrm{m}}\right)$ & $31-32$ & $27-29$ & $29-30$ & $28-29$ & $31 \neq$ & $29-31$ & $35-37$ & $30 \ddagger$ \\
\hline
\end{tabular}

*All strains require acetate for good growth.

$\dagger$ Miller \& Lin (2002) report that Methanobrevibacter smithii PS $^{\mathrm{T}}$ requires B vitamins.

$\ddagger$ Data from Miller \& Lin (2002).

$\S \mathrm{BF}$, Bovine faeces; BRC, bovine rumen contents; EF, equine faeces; HF, human faeces; ORC, ovine rumen contents; PF, porcine faeces; $\mathrm{S}$, sewage. 
strains of recognized Methanobrevibacter species isolated from ruminant sources (also Methanobrevibacter thaueri $\mathrm{CW}^{\mathrm{T}}$ and Methanobrevibacter wolinii $\mathrm{SH}^{\mathrm{T}}$ ) that is able to use formate plus $\mathrm{CO}_{2}$. This is surprising, given that formate may be an important substrate for methanogenesis in the rumen (Lovley et al., 1984; Asanuma et al., 1999).

Cell yields were 2-3 times less when strains $\mathrm{ZA}-10^{\mathrm{T}}$, $\mathrm{KM} 1 \mathrm{H} 5-1 \mathrm{P}^{\mathrm{T}}$, Methanobrevibacter ruminantium $\mathrm{M1}^{\mathrm{T}}$ and Methanobrevibacter smithii $\mathrm{PS}^{\mathrm{T}}$ were grown on formate instead of $\mathrm{H}_{2} / \mathrm{CO}_{2}$. Formate at concentrations greater than $150 \mathrm{mM}$ increased growth of Methanobrevibacter smithii $\mathrm{PS}^{\mathrm{T}}\left(\mathrm{OD}_{660}=0.597\right.$ at $290 \mathrm{mM}$ formate $)$ and strain $\mathrm{KM} 1 \mathrm{H} 5-1 \mathrm{P}^{\mathrm{T}}\left(\mathrm{OD}_{660}=0.578\right.$ at $220 \mathrm{mM}$ formate $)$, but inhibited growth of Methanobrevibacter ruminantium $\mathrm{M1}^{\mathrm{T}}$ $\left(\mathrm{OD}_{660}=0.09\right.$ at $220 \mathrm{mM}$ formate $)$ and did not increase growth of strain ZA-10 $0^{\mathrm{T}}\left(\mathrm{OD}_{660}=0.25\right.$ at $220 \mathrm{mM}$ formate). This may be due to the free energy available for methanogenesis being greater for hydrogen than for formate [-130 and $-119 \mathrm{~kJ}\left(\mathrm{~mol} \mathrm{CH}_{4}\right)^{-1}$, respectively] (Muller et al., 1993).

For Methanobrevibacter smithii $\mathrm{PS}^{\mathrm{T}}$, strain $\mathrm{KM} 1 \mathrm{H} 5-1 \mathrm{P}^{\mathrm{T}}$ and strain $\mathrm{ZA}-10^{\mathrm{T}}$, the ratio of formate consumed to methane produced was in approximate agreement with that expected from the stoichiometry $(4: 1)$ of the methanogenic reaction (Muller et al., 1993; Morii et al., 1983). For Methanobrevibacter ruminantium $\mathrm{M1}^{\mathrm{T}}$, the ratio was not as expected $(0.92: 1)$. The substrate did not become limited and the $\mathrm{pH}$ of the formate-grown cultures was maintained for all strains within one unit of the optimal $\mathrm{pH}$ that Daniels et al. (1984) concluded was an acceptable range for good growth. It is possible that the growth was not coupled to methane production because the cells were generating methane for cell maintenance rather than growth (Sowers \& Noll, 1995) due to increasing salt concentrations. Growth parameters for strains ZA-10 ${ }^{\mathrm{T}}, \mathrm{KM} 1 \mathrm{H} 5-1 \mathrm{P}^{\mathrm{T}}$, Methanobrevibacter smithii $\mathrm{PS}^{\mathrm{T}}$ and Methanobrevibacter ruminantium $\mathrm{M}^{\mathrm{T}}$ on $\mathrm{H}_{2} / \mathrm{CO}_{2}(80: 20)$ and on formate plus $\mathrm{CO}_{2}$ are given in Supplementary Table S1 (available in IJSEM Online).

The percentage cell-wall protein of the total cell protein for strains ZA- $10^{\mathrm{T}}, \mathrm{KM} 1 \mathrm{H} 5-1 \mathrm{P}^{\mathrm{T}}$ and $\mathrm{AK}-87$ was $85.5,86.0$ and $85.8 \%$, respectively, and for the three reference strains Methanobrevibacter ruminantium $\mathrm{M}^{\mathrm{T}}$, Methanobrevibacter smithii $\mathrm{PS}^{\mathrm{T}}$ and Methanobrevibacter arboriphilus $\mathrm{DH}-1^{\mathrm{T}}$ was $85.2,85.9$ and $86.6 \%$, respectively. The carbohydrate content of the cell walls varied between 21.7 and $44.0 \%$ among these strains: $\mathrm{ZA}-10^{\mathrm{T}}, 26.2 \%$; KM1H5- $1 \mathrm{P}^{\mathrm{T}}$, no result; AK-87, 32.9\%; Methanobrevibacter ruminantium $\mathrm{M}^{\mathrm{T}}$, $44.0 \%$; Methanobrevibacter smithii $\mathrm{PS}^{\mathrm{T}}, 27.0 \%$; Methanobrevibacter arboriphilus $\mathrm{DH}-1^{\mathrm{T}}, 21.7 \%$. These results compared favourably with those reported by Kandler \& Konig (1985), who calculated the carbohydrate content of the cell walls of Methanobrevibacter arboriphilus $\mathrm{DH}-\mathrm{1}^{\mathrm{T}}$, Methanobrevibacter smithii $\mathrm{PS}^{\mathrm{T}}$ and Methanobrevibacter ruminantium $\mathrm{M1}^{\mathrm{T}}$ to be 19,27 and $41 \%$, respectively.
The percentage of cell-wall protein compared with the total cell protein did not aid in delineating between the Methanobrevibacter species; however, the carbohydrate content of the cell walls varied considerably between the new and reference strains, with the exception of Methanobrevibacter smithii $\mathrm{PS}^{\mathrm{T}}$ and strain $\mathrm{ZA}-10^{\mathrm{T}}$. A more thorough examination of the carbohydrate content of the cell walls of Methanobrevibacter species is warranted as this may provide another useful taxonomic tool.

Stackebrandt \& Goebel (1994) determined that, for the domain Bacteria, > $97 \%$ 16S rRNA gene sequence similarity generally corresponded to $>70 \%$ DNA reassociation. Lin \& Miller (1998) concluded that, for the genus Methanobrevibacter, >99\% 16S rRNA gene sequence similarity corresponded to $>70 \%$ DNA reassociation. This conclusion is generally supported by the data from the present study, as the four strains ZA-10 ${ }^{\mathrm{T}}, \mathrm{KM} 1 \mathrm{H} 5-1 \mathrm{P}^{\mathrm{T}}$, OCP and AK-87 showed DNA reassociation values of $>70 \%$ when $16 \mathrm{~S}$ rRNA gene sequence similarity was $>99 \%$. An exception was between strains OCP and AK-87, which shared a $16 \mathrm{~S}$ rRNA gene sequence similarity of $98.6 \%$ and DNA reassociation value of $76 \%$.

The closest recognized relative to strain $\mathrm{ZA}-10^{\mathrm{T}}$ was Methanobrevibacter thaueri $\mathrm{CW}^{\mathrm{T}}(98.0 \%$ 16S rRNA gene sequence similarity), followed by Methanobrevibacter smithii $\mathrm{PS}^{\mathrm{T}}(97.9 \%)$ and Methanobrevibacter gottschalkii $\mathrm{HO}^{\mathrm{T}}$ (97.5\%). DNA-DNA hybridization experiments revealed only $28 \%$ DNA reassociation between strains $\mathrm{ZA}-10^{\mathrm{T}}$ and Methanobrevibacter thaueri $\mathrm{CW}^{\mathrm{T}}$, indicating that $\mathrm{ZA}-10^{\mathrm{T}}$ was not a strain of Methanobrevibacter thaueri. ZA- $10^{\mathrm{T}}$ was also not related to Methanobrevibacter smithii or Methanobrevibacter gottschalkii, as it shared $<25 \%$ DNA reassociation with the type strains of these species. Based on these data, strain ZA- $10^{\mathrm{T}}$ appeared to be unique. Strain ZA$10^{\mathrm{T}}$ grouped with the New Zealand sheep rumen isolate SM9 with a $16 \mathrm{~S}$ rRNA gene sequence similarity of $99.3 \%$ (Fig. 1).

The closest recognized relative to strain $\mathrm{KM} 1 \mathrm{H} 5-1 \mathrm{P}^{\mathrm{T}}$ was Methanobrevibacter ruminantium $\mathrm{M}^{\mathrm{T}}$, with a $16 \mathrm{~S}$ rRNA gene sequence similarity of $98.6 \%$, followed by Methanobrevibacter smithii $\mathrm{PS}^{\mathrm{T}}$ (94.5\%). However, there was $<25 \%$ DNA-DNA hybridization between strain KM1H5$1 \mathrm{P}^{\mathrm{T}}$ and either Methanobrevibacter ruminantium $\mathrm{M}^{\mathrm{T}}$ or Methanobrevibacter smithii $\mathrm{PS}^{\mathrm{T}}$. The closest cultured organisms to strain $\mathrm{KM} 1 \mathrm{H} 5-1 \mathrm{P}^{\mathrm{T}}$ were strains OCP and AK-87 with $16 \mathrm{~S}$ rRNA gene sequence similarities of 99.5 and $99.1 \%$, respectively, and DNA reassociation values of 86 and $87 \%$, respectively. Based on these results, strain KM1H5$1 \mathrm{P}^{\mathrm{T}}$ and strains OCP and AK-87 appeared to be related and to form a unique group. Levels of $16 \mathrm{~S}$ rRNA gene sequence similarity and DNA-DNA hybridization values for the four new strains and the type strains of Methanobrevibacter thaueri, Methanobrevibacter gottschalkii, Methanobrevibacter smithii and Methanobrevibacter ruminantium are given in Supplementary Table S2 (available in IJSEM Online). The ability to utilize formate plus $\mathrm{CO}_{2}$ appeared to be strainspecific, given that strain KM1H5-1 $\mathrm{P}^{\mathrm{T}}$ was able to utilize 


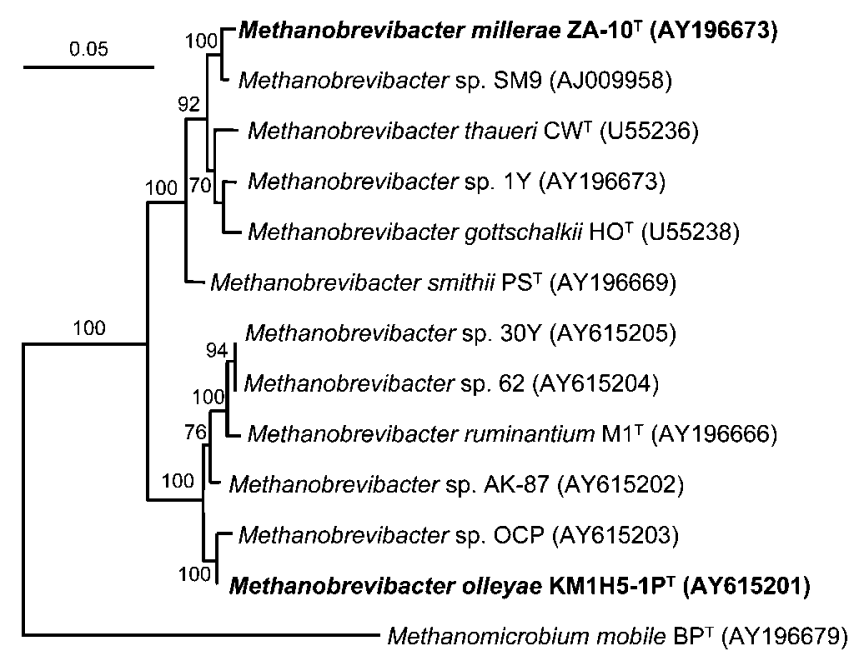

Fig. 1. Fitch-Margoliash (FITCH) tree of strains $Z A-10^{\top}$ and KM1H5-1 $\mathrm{P}^{\top}$ plus related strains of Methanobrevibacter based on 16S rRNA gene sequences (1283 bp) using Kimura twoparameter genetic distances. Methanomicrobium mobile $\mathrm{BP}^{\top}$ was used as the outgroup. Bootstrap support percentages (1000 replicates) $>50 \%$ are shown on internal nodes and GenBank accession numbers are given in parentheses. Bar, 5 changes per $100 \mathrm{nt}$.

formate for methanogenesis, but strains OCP and AK-87 could not. Asakawa et al. (1993) also observed that strains of Methanobrevibacter arboriphilus varied in their ability to use formate.

In addition to the $16 \mathrm{~S}$ rRNA gene sequence similarity data and DNA reassociation values, the data in Table 1 provide support for the creation of two novel species to accommodate the new strains described here. Strain $\mathrm{ZA}-10^{\mathrm{T}}$ differed from its closest relative Methanobrevibacter thaueri $\mathrm{CW}^{\mathrm{T}}$ in its ability to tolerate $2.6 \% \mathrm{NaCl}$ and by its ability to use formate plus $\mathrm{CO}_{2}$ as carbon and energy source. The $\mathrm{G}+\mathrm{C}$ content of the DNA for Methanobrevibacter thaueri $\mathrm{CW}^{\mathrm{T}}$ was also quite high (35-37 mol\%) compared with strain ZA-10 ${ }^{\mathrm{T}}$ (31-32 mol\%). Strain KM1H5-1P ${ }^{\mathrm{T}}$ and Methanobrevibacter ruminantium $\mathrm{M}^{\mathrm{T}}$ were isolated from ovine and bovine rumen contents, respectively, and they differed in their nutritional requirements. Strain KM1H5$1 \mathrm{P}^{\mathrm{T}}$ was able to grow in a salts medium plus $\mathrm{H}_{2} / \mathrm{CO}_{2}$ $(80: 20)$ with only the addition of acetate, whereas Methanobrevibacter ruminantium $\mathrm{M1}^{\mathrm{T}}$ required the addition of yeast extract and trypticase peptone for growth. Strain KM1H5-1P $\mathrm{P}^{\mathrm{T}}$ was also able to fulfil its own requirements for co-enzyme $\mathrm{M}$, whereas Methanobrevibacter ruminantium $\mathrm{M}^{\mathrm{T}}$ lacked this ability.

The results presented herein indicate that strains $\mathrm{ZA}-10^{\mathrm{T}}$ and KM1H5- $1 \mathrm{P}^{\mathrm{T}}$ should be classified as representing separate novel species of the genus Methanobrevibacter. Neither strain had $>70 \%$ DNA reassociation with recognized species of the genus Methanobrevibacter or with each other. Levels of $16 \mathrm{~S}$ rRNA gene sequence similarity were $<99 \%$ in comparisons with recognized species of the genus Methanobrevibacter and in comparisons with each other, which was shown by Lin \& Miller (1998) and in this study generally to correspond to $<70 \%$ DNA reassociation. We therefore propose the creation of two novel Methanobrevibacter species, Methanobrevibacter millerae sp. nov. and Methanobrevibacter olleyae sp. nov. With the description of these two novel species, the number of Methanobrevibacter species isolated from ruminant sources that can grow on formate plus $\mathrm{CO}_{2}$ increases from one to three (also Methanobrevibacter ruminantium).

\section{Description of Methanobrevibacter millerae sp. nov.}

Methanobrevibacter millerae (mil'ler.ae. N.L. gen. n. millerae of Miller, named for Dr Terry Miller for her contributions to the taxonomy of methanogens, in particular the genus Methanobrevibacter).

Cells occur singly or in pairs or chains and are coccobacilli $(0.5-1.2 \mu \mathrm{m})$ with rounded ends. Cells stain Gram-positive, are non-motile and are resistant to lysis by $10 \%$ SDS. Grows and produces methane from $\mathrm{H}_{2} / \mathrm{CO}_{2}$ and from formate plus $\mathrm{CO}_{2}$. Acetate, methanol, ethanol, 2-propanol, 2-butanol, methylamine and trimethylamine are not utilized as substrates. Requires acetate and one or more components of yeast extract and trypticase peptone for growth. Does not require co-enzyme $\mathrm{M}$ or fatty acids for growth but fatty acids can stimulate growth. Bile-sensitive. Mesophilic. No growth in BRN medium below $33^{\circ} \mathrm{C}$ or above $43^{\circ} \mathrm{C}$; optimum temperature range for growth is $36-42^{\circ} \mathrm{C} . \mathrm{pH}$ range for growth is $5.5-10.0$; optimum $\mathrm{pH}$ is $7.0-8.0$. The maximum salt tolerance for growth is $2.6 \%$. The DNA $\mathrm{G}+\mathrm{C}$ content is $31-32 \mathrm{~mol} \%\left(T_{\mathrm{m}}\right)$.

The type strain, ZA $-10^{\mathrm{T}}\left(=\mathrm{DSM} 16643^{\mathrm{T}}=\mathrm{OCM} 820^{\mathrm{T}}\right)$, was isolated from enrichments of bovine rumen contents.

\section{Description of Methanobrevibacter olleyae sp. nov.}

Methanobrevibacter olleyae (ol'ley.ae. N.L. gen. n. olleyae of Olley, named for Dr June Olley for her contributions to food microbiology).

Cells occur singly or in pairs and are coccobacilli $(0.3-1.0 \mu \mathrm{m})$ with rounded ends. Cells stain Gram-positive, although some variability is evident. Non-motile and resistant to lysis by $10 \%$ SDS. Grows and produces methane from $\mathrm{H}_{2} / \mathrm{CO}_{2} \quad(80: 20)$ and from formate plus $\mathrm{CO}_{2}$ (reference strains OCP and AK-87 cannot utilize formate plus $\mathrm{CO}_{2}$ ). Acetate, methanol, ethanol, 2-propanol, 2butanol, methylamine and trimethylamine are not utilized as substrates. Requires acetate for growth and does not require co-enzyme $\mathrm{M}$ or fatty acids. Strain OCP requires yeast extract and peptone in addition to acetate, and strain AK-87 requires co-enzyme $\mathrm{M}$ and fatty acids in addition to these. Bile-sensitive. Mesophilic. No growth in BRN 
medium below $28{ }^{\circ} \mathrm{C}$ or above $42{ }^{\circ} \mathrm{C}$, although the temperature range for strain $\mathrm{AK}-87$ is restricted to $36-43{ }^{\circ} \mathrm{C}$. The optimum temperature range for growth is $28-42^{\circ} \mathrm{C}$. $\mathrm{pH}$ range for growth is $6.0-10.0$; optimum $\mathrm{pH}$ is 7.5. The maximum salt tolerance for growth is $2.6 \%$, although growth is inhibited in strain AK- 87 at this concentration. The DNA G+C content is $27-29 \mathrm{~mol} \%$ $\left(T_{\mathrm{m}}\right)$.

The type strain, KM1H5-1P $\mathrm{P}^{\mathrm{T}}\left(=\mathrm{DSM} \quad 16632^{\mathrm{T}}=\mathrm{OCM}\right.$ $841^{\mathrm{T}}$ ), was isolated from enrichments of sheep rumen contents. Reference strains OCP and AK-87 were isolated from enrichments of bovine rumen contents.

\section{Acknowledgements}

We thank Dr Terry Miller (Wadsworth Center, Albany, NY, USA) for providing us with strain ZA- $10^{\mathrm{T}}$ and Ms Clare Auckland and Mr Louis Klein for their technical assistance. We also thank Dr Wendy Robertson and Dr Stuart Denham for critical comments on the manuscript.

\section{References}

Asakawa, S., Morii, H., Akagawa-Matsushita, M., Koga, Y. \& Hayano, K. (1993). Characterization of Methanobrevibacter arboriphilicus SA isolated from a paddy field soil and DNA-DNA hybridization among M. arboriphilicus strains. Int J Syst Bacteriol 43, 683-686.

Asanuma, N., Iwamoto, M. \& Hino, T. (1999). The production of formate, a substrate for methanogenesis, from compounds related with the glyoxylate cycle by mixed ruminal microbes. Anim Sci Technol 70, 67-73.

Balch, W. E., Fox, C. E., Magrum, L. J., Woese, C. R. \& Wolfe, R. S. (1979). Methanogens: reevaluation of a unique biological group. Microbiol Rev 43, 260-296.

Boone, D. R. \& Whitman, W. B. (1988). Proposal of minimal standards for describing new taxa of methanogenic bacteria. Int J Syst Bacteriol 38, 212-219.

Bowman, J. P., McCammon, S. A., Brown, J. L. \& McMeekin, T. A. (1998). Glaciecola punicea gen. nov., sp. nov. and Glaciecola pallidula gen. nov., sp. nov.: psychrophilic bacteria from Antarctic sea-ice habitats. Int J Syst Bacteriol 48, 1213-1222.

Daniels, L., Belay, N. \& Mulchopadahyay, B. (1984). Considerations for the use and large-scale growth of methanogenic bacteria. Biotechnol Bioeng Symp 14, 199-213.

Felsenstein, J. (1985). Confidence limits on phylogenies: an approach using the bootstrap. Evolution 39, 783-791.

Felsenstein, J. (2004). PHYLIP (phylogeny inference package), version 3.62c. Department of Genome Sciences, University of Washington, Seattle, USA.

Gerhardt, P., Murray, R. G. E., Wood, W. A. \& Krieg, N. R. (1994), Methods for General and Molecular Bacteriology. Washington, DC: American Society for Microbiology.

Huß, V. A. R., Festl, H. \& Scleifer, K.-H. (1983). Studies on the spectrophotometric determination of DNA hybridisation from renaturation rates. Syst Appl Microbiol 4, 184-192.

Kandler, O. \& Konig, H. (1985). Cell envelopes of Archebacteria. In The Bacteria, vol. 8, Archaebacteria, pp. 413-457. Edited by C. R. Woese \& R. S. Wolfe. New York: Academic Press.
Kicic, A. (1995). Bovine rumen methanogens - isolation and presumptive identification. Honours thesis, University of Western Australia, Nedlands, WA, Australia.

Kimura, M. (1980). A simple method of estimating evolutionary rates of base substitutions through comparative studies of nucleotide sequences. J Mol Evol 16, 111-120.

Konig, H. (1995). Isolation and analysis of cell walls from methanogenic Archaea. In Archaea: a Laboratory Manual, vol. 2, Methanogens, pp. 315-328. Edited by K. R. Sowers \& H. T. Schreier. Cold Spring Harbor, NY: Cold Spring Harbor Laboratory Press.

Lin, C. \& Miller, T. L. (1998). Phylogenetic analysis of Methanobrevibacter isolated from feces of humans and other animals. Arch Microbiol 169, 397-403.

Lovley, D. R., Greening, R. C. \& Ferry, J. G. (1984). Rapidly growing rumen methanogenic organism that synthesizes coenzyme $\mathrm{M}$ and has a high affinity for formate. Appl Environ Microbiol 48, 81-87.

Marmur, J. \& Doty, P. (1962). Determination of the base composition of deoxyribonucleic acid from its thermal denaturation temperature. J Mol Biol 5, 109-118.

Miller, T. L. (2001). Genus II. Methanobrevibacter Balch and Wolfe $1981,216^{\mathrm{VP}}$. In Bergey's Manual of Systematic Bacteriology, 2nd edn, vol. 1, pp. 218-226. Edited by D. R. Boone \& R. W. Castenholz. New York: Springer.

Miller, T. L. \& Lin, C. (2002). Description of Methanobrevibacter gottschalkii sp. nov., Methanobrevibacter thaueri sp. nov., Methanobrevibacter woesei sp. nov. and Methanobrevibacter wolinii sp. nov. Int J Syst Evol Microbiol 52, 819-822.

Miller, T. L., Wolin, M. J., Conway de Macario, E. \& Macario, A. J. L. (1982). Isolation of Methanobrevibacter smithii from human feces. Appl Environ Microbiol 43, 227-232.

Morii, H., Nishihara, M. \& Koga, Y. (1983). Isolation, characterization and physiology of a new formate assimilable methanogenic strain (A2) of Methanobrevibacter arborphilicus. Agric Biol Chem 47, 2781-2789.

Muller, V., Blaut, M. \& Gottschalk, G. (1993). Bioenergetics of methanogenesis. In Methanogenesis: Ecology, Physiology, Biochemistry and Genetics, pp. 360-406. Edited by J. G. Ferry. New York: Chapman \& Hall.

Munyard, K. (2000). Ecology of methanogens in the rumen. $\mathrm{PhD}$ thesis, University of Western Australia, Nedlands, WA, Australia.

Prescott, L. M., Harley, J. P. \& Klein, D. A. (1999). Microbiology, 4th edn. New York: WCB/McGraw-Hill.

Savant, D. V., Shouche, Y. S., Prakash, S. \& Ranade, D. R. (2002). Methanobrevibacter acididurans sp. nov., a novel methanogen from a sour anaerobic digester. Int J Syst Evol Microbiol 52, 1081-1087.

Sly, L. I., Blackall, L. L., Kraat, P. C., Tian-Shen, T. \& Sangkhobol, V. (1986). The use of second derivative plots for the determination of mol\% guanine plus cytosine of DNA by the thermal denaturation method. J Microbiol Methods 5, 139-156.

Sowers, K. R. \& Noll, K. M. (1995). Techniques for anaerobic growth. In Archaea: a Laboratory Manual, vol. 2, Methanogens, pp. 15-48. Edited by K. R. Sowers \& H. T. Schreier. Cold Spring Harbor, NY: Cold Spring Harbor Laboratory Press.

Stackebrandt, E. \& Goebel, B. M. (1994). Taxonomic note: a place for DNA-DNA reassociation and 16S rRNA sequence analysis in the present species definition in bacteriology. Int J Syst Bacteriol 44, 846-849.

Wright, A.-D. G. \& Pimm, C. (2003). Improved strategy for presumptive identification of methanogens using $16 \mathrm{~S}$ riboprinting. J Microbiol Methods 55, 337-349. 
Wright, A.-D. G., Kennedy, P., O'Neill, C., Toovey, A. F., Popovski, S., Rea, S. M., Pimm, C. L. \& Klein, L. (2004a). Reducing methane emissions in sheep by immunization against rumen methanogens. Vaccine 22, 3976-3985.
Wright, A.-D. G., Williams, A. J., Winder, B., Christophersen, C. T., Rodgers, S. L. \& Smith, K. D. (2004b). Molecular diversity of rumen methanogens from sheep in Western Australia. Appl Environ Microbiol 70, 1263-1270. 